\title{
Remote Sensing of City Extension and Vegetal Cover Changes along Lagos-Ibadan Access Strip in Nigeria
}

\section{*OYEDEPO, JA; OLUYEGE, DE; BABAJIDE, EI}

\author{
Institute of Food Security, Environmental Resources and Agricultural Resources (IFSERAR) Federal University of Agriculture, Abeokuta \\ Nigeria \\ "Corresponding Author Email: johnoyedepo@gmail.com; Tel: +2348032485583
}

\begin{abstract}
The paper employed Remote sensing data in a multi-decadal assessment of vegetal to urban land cover transition along Lagos-Ibadan expressway. The forty-year assessment commenced in 1980 and ended in 2020. Landsat imageries acquired for the respective periods were subjected to supervised classification. Results reveal massive conversion of vegetated areas into built-up areas. The transition became pronounced from the second decade with 30,226 and cumulative of 48,455 Hectares of vegetation transforming into built-up area. During the third decade (2000 to 2010), additional 44,780 and cumulative of 93,235 Hectares of green area was converted into built-up areas. The largest transition was recorded in the last decade (2010 to 2020) during which vegetated area covering 50,827 Hectares was converted to living or industrial areas giving a cumulative transition of 141,065 in year 2020 Pearson moment correlation showed a high negative correlation with a coefficient value of -0.86 . Hectares of vegetal areas into built-up or bare surfaces.
\end{abstract}

\section{DOI: https://dx.doi.org/10.4314/jasem.v25i8.13}

Copyright: Copyright $\odot 2021$ Oyedepo et al. This is an open access article distributed under the Creative Commons Attribution License (CCL), which permits unrestricted use, distribution, and reproduction in any medium, provided the original work is properly cited.

Dates: Received: 10 May 2021; Revised: 28 June 2021; Accepted: 01 July 2021

Keywords: Vegetal cover transition, Lagos-Ibadan corridor, decadal change assessment

The combination of satellite remote sensing and geospatial technics has been very useful in monitoring urban sprawl, forest transition and vegetation dynamics (Xie et al., 2008; Kumar, 2011; Mensah et al., 2019; Lechner et al., 2020). Analysis of satellite remote sensing data presents opportunity to characterize changes over wide landscape areas due to the extent of its coverage, the temporal resolution, wide period of acquisition and ease of analysis (Liu and Yang, 2015; Roy et al., 2017; Crowley and Cardille, 2020). Satellite imageries have been available for more than four and a half decades (Tatem et al., 2008; Cracknell, 2018) this therefore gives room for conducting change analysis that are required in vegetal-cover dynamics. The availability of Landsat TM imageries since 1975, permits land change modeling, periodic assessment and future change prediction (Reveshty, 2011; Wulder et al., 2019; Tadese et al., 2021).

The creation of the Lagos-Ibadan express way in 1978 in response to the crucial need to link the seaports to other parts of the country, led to opening up of a major part of lowland rainforest region in South-west Nigeria (Falako, 2017). The construction of this major corridor through the jungle of south-western Nigeria, led to large scale degradation of its forest over the decades.
Nguyen, et al., (2020) noted that capital cities will continue to absorb population influx from the country sides, with concomitant pressures arising from increased demand of industrial and residential quarters within city core (Lawanson et al., 2017). The implication of this for a city like Lagos is increased number and sizes of satellite towns around the metropolis. Pressures will consequently mount up on the green belt regions around the city as well as in the neighboring communities. The impressions of these pressures appear as changes in vegetation condition and alteration of physical landscapes (Gaston et al., 2013; McGrane et al., 2016). Lasisi et al., (2017) clearly pointed out that vegetation in city outskirts are the first to be affected in the process of city expansion. Meanwhile, vegetation is of critical importance in terrestrial ecosystem mechanisms (Yapp et al., 2010). Vegetation has important consequences as primary producers and habitats for other biotic components of the terrestrial ecosystem, and in the goods and services provided to mankind and his environment (Smith $e t$ al., 2011).

Synoptic view of the south-western Nigeria through satellite image is considered very important in order to show the fragmentation that the once dense vegetation has experienced. It is also vital to understand the entire 
landscape, with the aim of assessing the fraction of the lowland rainforest of 1975 that remain. At the moment, several portions of the area have become industrialized or covered by extensive living quarters. Meanwhile, to date, there has been very little effort at assessing the land use/land cover changes of the area in the last four decades. There is a very urgent need to protect the remaining precinct environments as part of the conservation plan in the country.

The objectives of the study were therefore to: determine the spatial patterns of deforestation and urbanization over time with the intention of taking stock and forecasting for the remaining vegetation along the corridor.

\section{MATERIALS AND METHODS}

Study Area: The study area is described by Latitudes $6^{0} 34^{\prime}$ to $7^{0} 4^{\prime} \mathrm{N}$ and Longitudes $3^{0} 11^{\prime}$ to $3^{0} 48^{\prime} 30^{\prime \prime} \mathrm{E}$ and is divided diagonally by a 127.6-kilometre dual carriage way that connects Lagos with Ibadan city. The expressway was commissioned in 1978 and has made the entire axis vulnerable to anthropogenic activities. The Lagos-Ibadan axis witnessed rapid clearing in the last 30 years. At the moment most of the area has been opened up as farm, industries, religious camps or residential quarters. Pockets of vegetation particularly, the riparian fringes are however, still precinct. The study area is now a mixture of human dominated ecosystem with vegetation which included fresh water marshes, farmlands interspersed with disturbed rainforest and savanna scrublands. The climate is typical of derived Savanah as against the tropical rainforest. Temperature ranges between $36^{\circ} \mathrm{Celcius}$ to $40^{\circ}$ Celcius. The general land use/land cover of the area is presented figure 1 .

Data type and data source: Landsat data acquired the years 1980, 1990, 2000, 2010 and 2020 were downloaded from the USGS website. The 1980 imagery was acquired using the LandSat 5 while that of 1990, 2000 and 2010 imagery were acquired using LandSat 7. The imagery for year 2020 was acquired using LandSat 8. The reason for the different sensors was because of the time and data of the respective data. National Oceanic and Atmospheric Administration (NOAA), who owns Landsat has had to upgrade the sensors at different period in the history of Landsat mission. These different sensors were however confirmed to be largely compatible with regards to the processing and analysis required for the study.

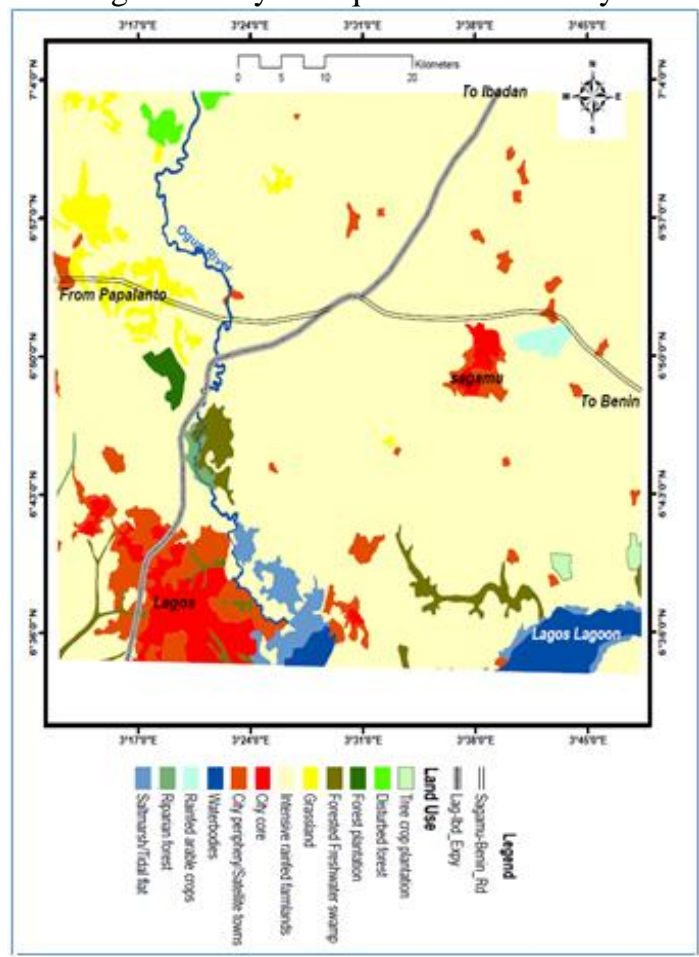

Fig. 1: The study area and the land use and cover types

Table 1: Secondary data used and their sources

\begin{tabular}{lll}
\hline Data types & Description & Sources \\
\hline LandSat 5 & Multispectral medium 60 meter resolution image (7 bands) & https://www.earthexplorer.usgs.gov \\
LandSat 7 & Multispectral medium 30 meter resolution image (8 bands) & https://www.earthexplorer.usgs.gov \\
LandSat 8 & Multispectral medium 30 meter resolution image (11 bands) & https://www.earthexplorer.usgs.gov \\
\hline
\end{tabular}
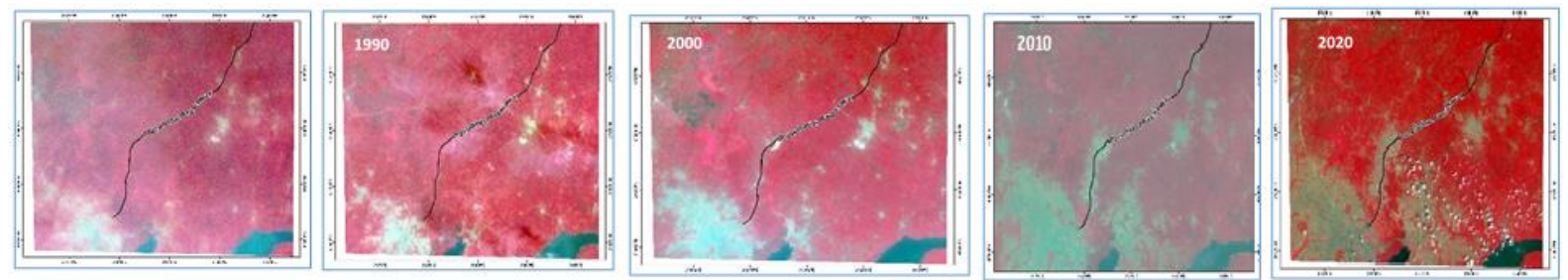

Fig. 2: False Colour Composite (FCC) of the landsat imageries for the five periods under review

Data processing: False Colour Composite: The images which came in multiple bands were stacked to produce a false colour composite for each period namely: 1980 to 2020 . Using the Composite tool from 
the Image Analysis toolbox, Band 3, 2, 1 was combined for the satellite image for 1980 while Band 4, 3, 2 was combined for the year 1990, 2000 and 2010 and Band 5, 4, 3 was combined for the year 2020 to get a false color (pseudo) image. The outcome of the false colour composite the various period are as shown below. The progressive increase in built-up areas and corresponding decrease in vegetation

Geometric correction: The area of interest was then clipped out from the images. The clipped set of images were geometrically corrected by registering them in Universal Transverse Mercator zone (UTM) 31.

Radiometric correction: A scan line error was present in the 2010 LandSat image. So the "Fix LandSat 7 Scanline error" tool from the LandSat toolbox to fix this error.

Image classification: Training Samples for three land use/ land cover classes of were created based on visual inspection of features physical recognition and. Vegetation, Water body and Built-up were picked for each year and each image was subject to a supervised classification using 5\% maximum likelihood to give the Land use and Land cover classifications.
Change detection analysis: The essence of the study was to investigate and analyze the changes that have occurred over the last decade in the particular segment of Lagos-Ibadan express way. Change analysis of Raster Calculator function of the ArcGIS spatial map Algebra was used to carry change detection analysis between year 1980-1990, 1990-2000, 2000-2010, and 2010-2020 respectively. This calculator subtracts land use identified in the lower year from the higher year. This helped identify land use that changed over the years.

\section{RESULTS AND DISCUSSION}

The interest of the study is in spatio-temporal analysis of vegetal cover in comparison with that of the builtup/bare surface areas, hence, the supervised classification was limited to three categories namely: vegetation, built-up areas and waterbodies. The land use/ land cover classification of the respective images acquired for 1980, 1990, 2000, 2010 and 2020 are presented in figures 3 (a-e); representing the five periods required to provide an overview of the land cover changes in four decades.

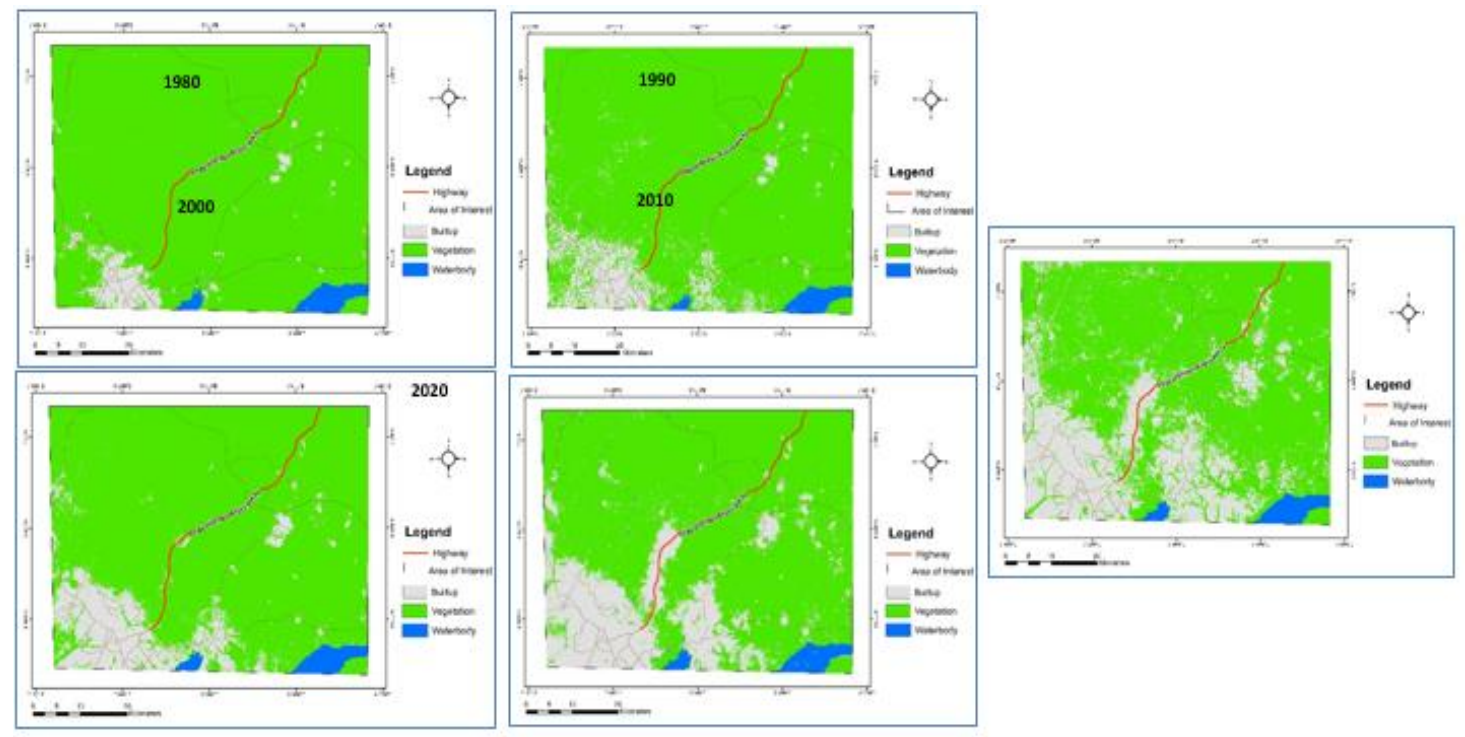

Fig. 3: Land cover types from supervised classification of Landsat imageries for the five periods

Table 2: Relative progression or regression in hectares of the land cover categories in the five periods

\begin{tabular}{lllllll}
\hline S/N & Land use / land cover categories & \multicolumn{6}{l}{ Hectares per period of assessment } \\
\cline { 3 - 7 } & & $\mathbf{1 9 8 0}$ & $\mathbf{1 9 9 0}$ & $\mathbf{2 0 0 0}$ & $\mathbf{2 0 1 0}$ & $\mathbf{2 0 2 0}$ \\
1 & Built-Up & 16352.28 & 34665.48 & 47812.05 & 81776.52 & 108394.8 \\
2 & Vegetation & 337417.2 & 319412.2 & 3060177 & 271324.2 & 245182.3 \\
3 & Water Body & 7375.32 & 6180.12 & 7165.8 & 7883.46 & 7647.12 \\
\hline
\end{tabular}

The progression or regression in sizes of respective land cover types can be observed from one period to another. As built up areas were increasing, the vegetated areas were reducing while water bodies 
appeared not to record any significant changes. In table 2 , the area actual area covered by the three land cover categories and their size over each of the five decades under review is presented.

In 1980, the entire study area was almost green with vegetation occupying 337417.2 Hectares (about 93 percent) of the study area. With the exception of the northern part of Lagos city sprawling into the green spaces and a few other locations dominated by humans, large portions of the area were forested. The Lagos-Ibadan corridor was barely 3 years in use in 1980 and most of the jungle are still precinct and yet to be populated by human residence or industries. The chart in figure 4 presents these trends in relative progression or regression more clearly. Table 3 shows the percentage area occupied by the respective land cover types in each period from 1980 to 2020.

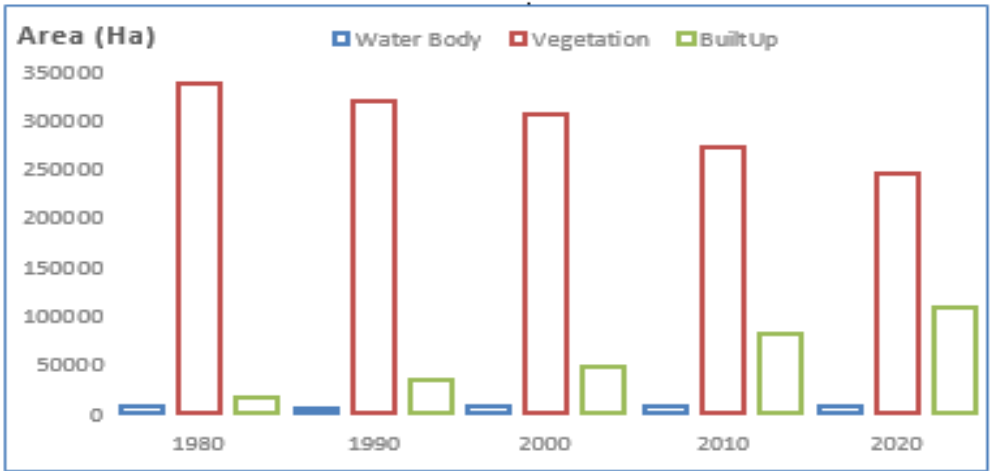

Fig. 4: Bar chart showing relative proportions of land cover types in each period

Table 3: Percentage area occupied by the respective land cover types

\begin{tabular}{llllll}
\hline Land cover types & 1980 & 1990 & 2000 & 2010 & 2020 \\
\hline Water Body & $2 \%$ & $2 \%$ & $2 \%$ & $2 \%$ & $2 \%$ \\
Vegetation & $93 \%$ & $89 \%$ & $85 \%$ & $75 \%$ & $68 \%$ \\
Built-up & $5 \%$ & $10 \%$ & $13 \%$ & $23 \%$ & $30 \%$ \\
\hline
\end{tabular}

The urban footprint of built up and bare land area had however significantly increased as from 5 percent in 1980 to 30 percent in 2020 . The consequence is that considerable amount of vegetation cover had been lost to residential and industrial quarters. In year 2010, the vegetated areas had begun to shrink considerably in size while human dominated environment received corresponding increase in size. By 2020, a massive change had occurred with regards to urban sprawl and loss of land occupied by vegetation cover and agriculture. It appears vegetation cover is being destroyed to satisfy the demands by the increasing population for residential, religious and industrial lands. A graph of changes through time elucidates the pattern of increase or decrease over the period of assessment. The graph of the above trend is presented in figure 5.

The observed trend from table 4 is that of inverse relationship between rate of change in area occupied by buildings and that occupied by vegetation as shown in the graph above. If the trend should continue, a simple projection implies that in another two and a half decades, there will be an intersection between vegetated area and built-up area. Implying that spatial coverage of built-up area would be at par with that of the vegetal cover. A Pearson's correlation analysis of the values of built-up areas and vegetated areas in table 2 revealed a highly positive relationship between the dynamics of vegetation and urban growth (built-up areas).

$$
r=\frac{\sum\left(x_{i}-\ddot{\mathrm{x}}\right)\left(y_{i}-\overline{\mathrm{y}}\right)}{\sqrt{\sum\left(x_{i}-\ddot{\mathrm{x}}\right)^{2} \sum\left(y_{i}-\overline{\mathrm{y}}\right)^{2}}}
$$

Where $r=$ correlation coefficient; $x_{i}=$ values of the $\mathrm{x}$-variable in a sample; $\ddot{x}=$ mean of the values of the $\mathrm{x}$-variable; $y_{i}=$ values of the $\mathrm{y}$-variable in a sample; $\overline{\mathrm{y}}$ $=$ mean of the values of the $y$-variable

Using the model above, the coefficient of correlation $\mathrm{r}$ was - 0.86145; implying very high negative correlation between built up areas and vegetated areas. It is however difficult to establish a cause and effect relationship between vegetal cover loss and gain in built-up area as correlation does not necessarily imply causality. DeFries et al. (2010) shows positive relationship between forest loss and urban population growth. As at 2000, the extent of vegetation including areas for agricultural croplands cover was $85 \%$ while area occupied by built-up land cover type was $23 \%$. 


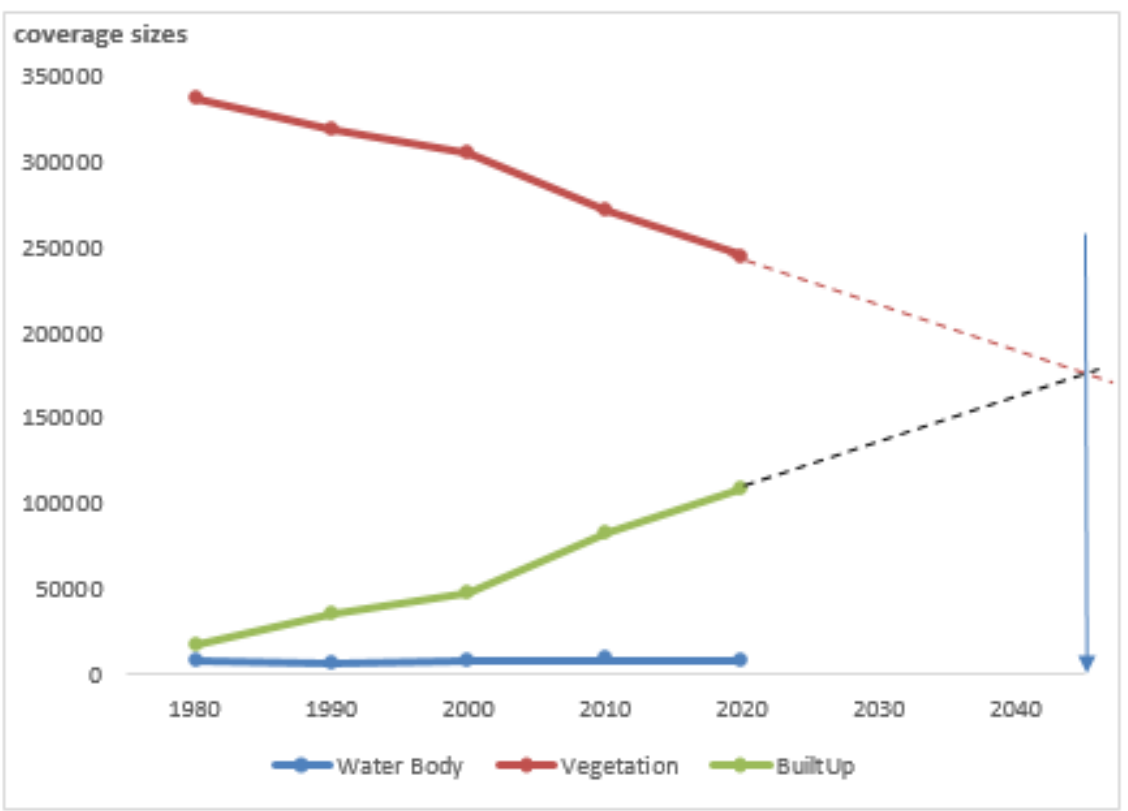

Fig. 5 Graph of progression and regression in size of respective land cover types

Change assessment of the land cover along LagosIbadan express way over 40 years: The overall comparison of each LULC class of 1980 and 2020 shows there has been a marked LULC change around the last 40 years. During the period, vegetation cover had decreased by $27 \%$ of its size in 1980 while builtup areas have increased by $500 \%$ of the original size in 1980. Area occupied by water has remain unchanged or with insignificant change. Transitional changes as presented in figures 3 (a-d) shows that most of the vegetated areas (including forests, farmlands and wetlands) have been transformed into human dominated vicinities. Table 5 presents a transition matrix across the four decades.

Table 5: The transition matrix of the three land cover types across the four decades

\begin{tabular}{|c|c|c|c|c|c|c|c|c|c|c|c|c|}
\hline $\begin{array}{l}\text { Land use } \\
\text { category }\end{array}$ & $\begin{array}{l}\text { Land Use } \\
1980\end{array}$ & ange f & $1990-$ & $\begin{array}{l}\text { Land Use } \\
1990\end{array}$ & ange fr & 12000 & $\begin{array}{l}\text { Land Use } \\
2000\end{array}$ & ge fi & 2010 & $\begin{array}{l}\text { Land U. } \\
2010\end{array}$ & hange f & $2020-$ \\
\hline & $\begin{array}{l}\text { Change } \\
\text { in area } \\
\text { (ha) }\end{array}$ & $\begin{array}{l}\% \\
\text { change }\end{array}$ & $\begin{array}{l}\text { Annual } \\
\text { average of } \\
\text { change (ha) }\end{array}$ & $\begin{array}{l}\text { Change } \\
\text { in area } \\
\text { (ha) }\end{array}$ & $\begin{array}{l}\% \\
\text { change }\end{array}$ & $\begin{array}{l}\text { Arnual } \\
\text { average of } \\
\text { change } \\
\text { (ha) }\end{array}$ & $\begin{array}{l}\text { Change in } \\
\text { area (ha) }\end{array}$ & $\begin{array}{l}\% \\
\text { change }\end{array}$ & $\begin{array}{l}\text { Arnual } \\
\text { average of } \\
\text { change } \\
\text { (ha) }\end{array}$ & $\begin{array}{l}\text { Change } \\
\text { in area } \\
\text { (ha) }\end{array}$ & $\begin{array}{l}\% \\
\text { change }\end{array}$ & $\begin{array}{l}\text { Annual } \\
\text { average of } \\
\text { change } \\
\text { (ha) }\end{array}$ \\
\hline $\begin{array}{l}\text { Water } \\
\text { Body }\end{array}$ & -899.52 & -0.25 & -89.952 & 686.55 & 0.19 & 68.655 & 774.66 & 0.21 & 77.466 & -316.41 & -0.09 & -31.641 \\
\hline $\begin{array}{l}\text { Vegetation } \\
\text { Built-up }\end{array}$ & $\begin{array}{c}-17709.3 \\
18608.88\end{array}$ & $\begin{array}{l}-4.91 \\
5.15\end{array}$ & $\begin{array}{l}-1770.936 \\
1860.888\end{array}$ & $\begin{array}{l}-13533.9 \\
12847.44\end{array}$ & $\begin{array}{l}-3.75 \\
3.56\end{array}$ & $\begin{array}{l}-1353.399 \\
1284.744\end{array}$ & $\begin{array}{l}-34796.13 \\
34021.47\end{array}$ & $\begin{array}{l}-9.64 \\
9.42\end{array}$ & $\begin{array}{l}-3479.613 \\
3401.147\end{array}$ & $\begin{array}{l}-26221.9 \\
26538.21\end{array}$ & $\begin{array}{l}-7.26 \\
7.35\end{array}$ & $\begin{array}{l}-2622.194 \\
2653.821\end{array}$ \\
\hline
\end{tabular}

It is clear from the table again that much of the vegetation is transforming into religious grounds or living and industrial areas. The first decade in the assessment, about 18,229 hectares of vegetation was changed into built up areas. This transition was higher in the second decade with 30,226 and cumulative of 48,455 Hectares of vegetation transforming into builtup area. During the third decade (2000 to 2010), additional 44,780 and cumulative of 93,235 Hectares of green area was converted into built-up areas. The largest transition was recorded in the last decade (2010 to 2020) during which vegetated area covering 50,827 Hectares was converted to living or industrial areas giving a cumulative transition of 141,065 Hectares of vegetal areas into built-up or bare surfaces. The spatial dimensions of these transitions can be seen in figure 4 (a-d). The explanation for the observed trend particularly from year 2000 can be rooted in two premises namely, the commencement of massive land clearing for religious activities. Major Pentecostal organization commenced opening of camp grounds along Lagos -Ibadan express way at the wake of year 2000. These led to many people working in Lagos coming to purchase lands for constructing personal buildings particularly when the cost of accommodation began to rise within Lagos metropolis. The second wage of forest transition to city occurred in at the beginning of year 2010, when industrialists began to move out of the city to establish factories. As at today, the city of Lagos is sprawling at leapfrog manner tenuously connecting with villages and major towns like Sagamu in neighboring Ogun State. 

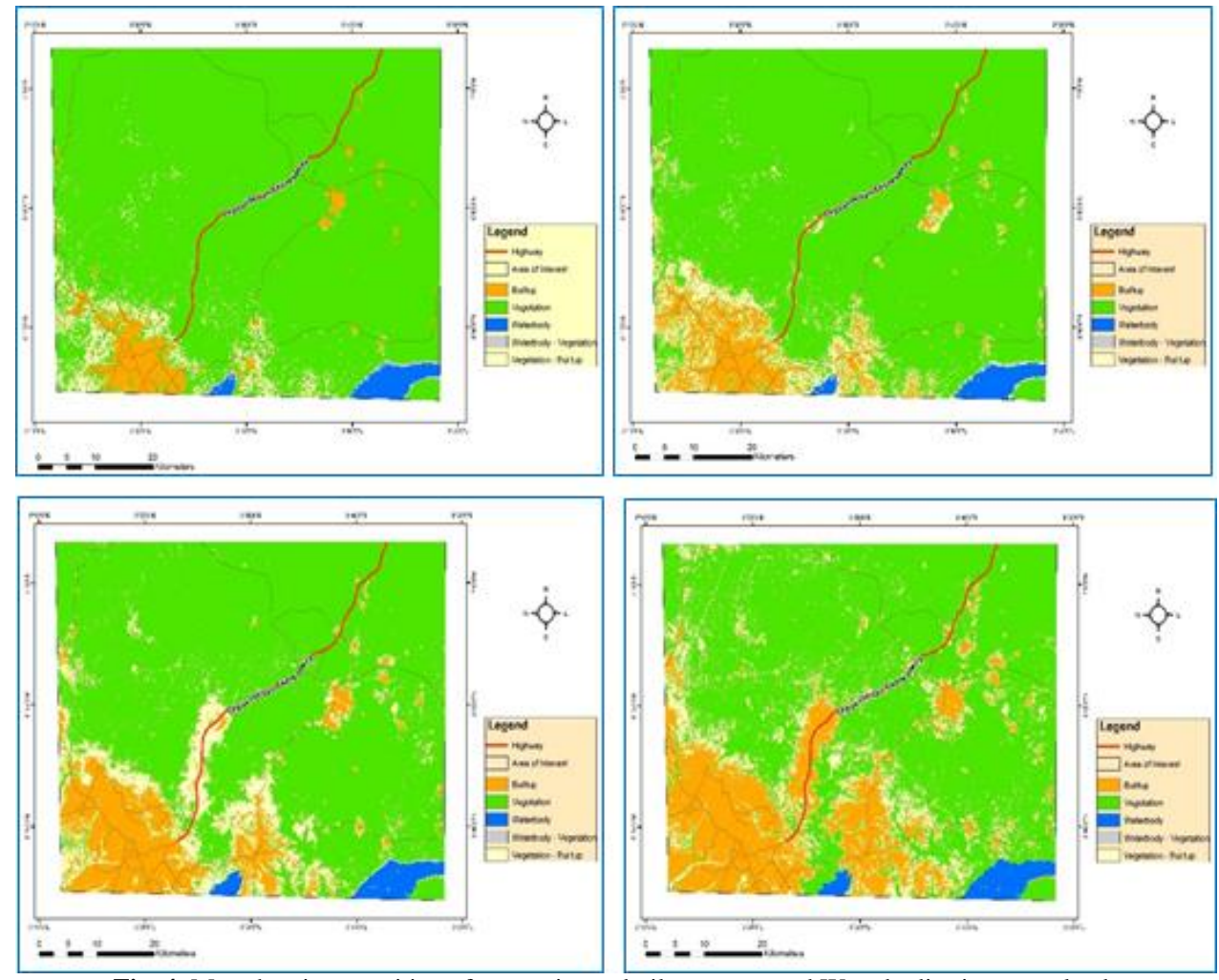

Fig. 4: Map showing transition of vegetation to built-up areas and Waterbodies into grasslands

Conclusion: Land cover changes over the last 40 years have significantly altered vegetation along LagosIbadan express way. Over 25 percent of the once forested lands are currently put to residential, commercial, industrial and religious use. Hundreds of hectares of forest, marshes, wooded savannah and farmlands have been converted to real estates and religious camp grounds (Falako, 2017). An inventory of the vegetation stock is suggested along the corridor to restrict further conversion of more arable lands into non-agricultural usage.

\section{REFERENCES}

Abubakar, IR and Doan, PL (2017) Building new capital cities in Africa: Lessons for new satellite towns in developing countries. African Studies, 76 (4): 546-565

Abubakar, IR (2014). Abuja city profile. Cities 41: 8191.

Cracknell, AP (2018). The development of remote sensing in the last 40 years, International Journal of Remote Sensing, 39 (23): 8387-8427

Crowley, MA and Cardille, JA (2020). Remote Sensing's Recent and Future Contributions to Landscape Ecology. Curr Landscape Ecol Rep 5: 45-57
Declet-Barreto, J; Brazel, AJ; Martin CA; Chow, WTL and Harlan SL (2013). Creating the park cool island in an inner-city neighborhood: heat mitigation strategy for Phoenix, AZ. Urban Ecosystems. 16 (3):617-635

Falako, FO (2017). Faith-based organizations and environmental hazards: a study of lagos-ibadan expressway, Nigeria. Nkuba Bus. Journal 17: 7380

Gaston KJ; Ávila-Jiménez, ML; Edmondson, JL (2013). Managing urban ecosystems for goods and services. Journal of Applied Ecology 50 (4):830840

Jenberu, AA; Admasu, TG (2020). Urbanization and land use pattern in Arba Minch town, Ethiopia: driving forces and challenges. GeoJournal 85: 761-778

Kumar, D (2011). Monitoring Forest Cover Changes Using Remote Sensing and GIS: A Global Prospective. Res. J. of Environmental Sciences, 5: $105-123$

Lasisi, M; Popoola, A; Adediji, A; Adedeji, O; Babalola, K (2017). City expansion and 
agricultural land loss within the peri-urban area of Osun State Nigeria. Ghana J. of Geog. 9 (3): 132163

Lawanson, T; Yadua, O; Salako, I (2017). Environmental Challenges of Peri-urban settlements in the Lagos In: Proceedings REAL CORP 2012 Tagungsband 14-16 May 2012, Schwechat. Editors: Schrenk, M. Popovich, V. V., Zeile, P. and Elisei P. (Eds.)

Lechner, AM; Foody, GM; Boyd, DS (2020). Applications in Remote Sensing to Forest Ecology and Management. One Earth, 2(5), 405-412

Liu, T; Yang, X (2015). Monitoring land changes in an urban area using satellite imagery, GIS and landscape metrics. Applied Geog. 56: 42-54

McGrane, SJ (2016). Impacts of urbanisation on hydrological and water quality dynamics, and urban water management: a review. Hydrological Sciences Journal 61(13):2295-2311

Mensah, AA; Sarfo, DA; Partey, ST (2019). Assessment of vegetation dynamics using remote sensing and GIS: A case of Bosomtwe Range Forest Reserve, Ghana. Egyptian J. Remote Sensing and Space Sci. 22 (2): 145-154

Reveshty, MA (2011). The Assessment and Predicting of Land Use Changes to Urban Area Using MultiTemporal Satellite Imagery and GIS: A Case Study on Zanjan, IRAN (1984-2011) JGIS 3 (4): 298-305

Roy, PS; Behera, MD; Srivastav, SK (2017). Satellite Remote Sensing: Sensors, Applications and Techniques. Proc. Natl. Acad. Sci., India, Sect. A Phys. Sci. 87: 465-472

Scott, AA; Misiani, H; Okoth, J; Jordan, A; Gohlke, J; Ouma, G, et al. (2017). Temperature and heat in informal settlements in Nairobi. PLOS ONE.12 (11) e0187300. Pmid: 29107977
Smith, N; Deal, R; Kline, J; Blahna, D; Patterson, T; Spies, TA; Bennett, K (2011). Ecosystem Services as a Framework for Forest Stewardship: Deschutes National Forest Overview. General Technical Report PNW-GTR-852

Tadese, S; Soromessa, T; Bekele, T (2021). Analysis of the Current and Future Prediction of Land Use/Land Cover Change Using Remote Sensing and the CA-Markov Model in Majang Forest Biosphere Reserves of Gambella, Southwestern Ethiopia, The Scientific World Journal, 2021, Article ID 6685045, 18 pgs.

Tatem, AJ; Goetz, SJ; Hay, SI (2008). Fifty Years of Earth Observation Satellites: Views from above have lead to countless advances on the ground in both scientific knowledge and daily life. American scientist, 96 (5): 390-398.

Wulder, MA; Loveland, TR; Roy, DP; Crawford, CJ; Masek, JG; Woodcock, CE; Allen, RG; Anderson, MC; Belward, AS; Cohen, WB; Erb, JDA; Gao, F; Griffiths, P; Helder, D; Hermosilla, T; Hipple, JD; Hostert, P; Hughes, MJ; Huntington, J; Johnson, DM; Kennedy, R; Kilic, A; Li, Z; Lymburner, L; McCorkel, J; Pahlevan, N; Scambos, TA; Schaaf, C; Schott, JR; Sheng, Y; Storey, J; Vermote, E; Vogelmann, J; White, JC; Wynne, RH; Zhu, Z (2019). Current status of Landsat program, science, and applications. Remote Sens. Environ. 225: 127147

Xie, Y; Sha, Z; Yu, M (2008). Remote sensing imagery in vegetation mapping: A review. Journal of Plant Ecology 1(1): 9-23

Yapp, G; Walker, J; Thackway, R (2010). Linking vegetation type and condition to ecosystem goods and services. Ecological Complexity 7(3):292-301 